\title{
Influence of grinding residual stresses on contact loading strength degradation in Y-TZP
}

\section{(Influência da tensão residual de polimento na degradação da resistência à carga de contato em Y-TZP)}

\author{
A. Juy ${ }^{1}$, M. Anglada ${ }^{2}$, H. C. Fals ${ }^{1}$, J. B. Fernandez ${ }^{3}$ \\ ${ }^{1}$ Universidad de Oriente, Santiago de Cuba, Cuba \\ ${ }^{2}$ Universitat Politècnica de Catalunya, Barcelona, España \\ ${ }^{3}$ Universidad de la Rioja, La Rioja, España
}

\begin{abstract}
The influence of grinding surface stresses in Y-TZP doped with 2.5\% molar yttria on the contact loading response has been studied. It is shown that by grinding with different pressures compression residual stresses are induced in a surface layer of about $10 \mu \mathrm{m}$ in depth. Their effect is manifested by shorter indentation cracks in ground specimens, but they recover the original lengths of annealed specimens after a surface thin layer is removed by polishing. The response to cyclic contact loading with a ball of $1.96 \mathrm{~mm}$ in diameter has been studied by looking to the damage that takes place below the indenter, as well as by measuring the flexure biaxial strength after $1,10^{3}$ and $10^{5}$ cycles and for different load amplitudes. It is found that there is a threshold load, that is, a maximum contact load below which there is no degradation in the strength. This threshold is lower when transformability is higher and it depends on the number of contact cycles. But after a given large number of cycles, no further important additional degradation takes place. Under repeated contact loading in annealed specimens at loads for which a marked degradation in strength is detected, nucleation and growth of like-radial cracks is the main cause for the loss of strength, while for of ground specimens the extension of these defects is impeded by the compression surface residual stresses.
\end{abstract}

Keywords: Contact fatigue, grinding residual stresses, tetragonal zirconia polycristals.

\section{Resumo}

\begin{abstract}
Foi estudada a influência das tensões de superficies de polimento em zircônia tetragonal policirstalina (Y-TZP) dopada com 2,5 mol\% itria na resposta à carga de contato. É mostrado que o polimento com diferentes tensões residuais de compressão devidas ao polimento são induzidas em uma camada da superficie de aproximadamente $10 \mu \mathrm{m}$ de profundidade. O seu efeito é manifestado por meio de pequenas trincas de indentação em amostras polidas, mas seus comprimentos originais são recuperados em amostras tratadas termicamente depois que uma fina camada é removida da superficie por meio de polimento. A resposta à carga de contato cíclica com uma esfera de 1,96 mm de diâmetro foi estudada observando o dano que acontece embaixo do indentador, e também medindo a resistência à flexão biaxial após $1,10^{3}$ e $10^{5}$ ciclos e para diferentes amplitudes de carga. É mostrado que existe uma carga limiar que é a carga de contato máximo abaixo da qual não há degradação na resistência. Este limiar é menos quando a transformabilidade é maior, e depende do número de ciclos de contato. Mas após um certo número de ciclos não acontece nenhuma degradação adicional importante. Sob repetidas cargas de contato em amostras tratadas termicamente sob cargas para as quais é detectada uma degradação acentuada de resistência, a nucleação e o crescimento de trincas radiais é a principal causa para a diminuição de resistência, enquanto em amostras polidas a extensão destes defeitos é impedida pelas tensões residuais de compressão de superficie.
\end{abstract}

Palavras-chave: fadiga de contato, tensões residuais de polimento, zircônia tetragonal policristalina.

\section{INTRODUCTION}

Zirconia ceramics have an excellent combination of fracture toughness and strength [1]. The tolerance and reliability of these materials under contact loads is an important issue in different applications. The selection of tetragonal zirconia polycrystals doped with yttria has some important advantages since their properties may be tailored to have different combinations of strength and fracture toughness by changing the microstructure. This may be achieved by means of sintering conditions or suitable heat treatments, which may change the transformability of metastable zirconia under an applied stress.

In addition, machining of these materials induces residual stresses, either because of plastic deformation or eventually by tetragonal-monoclinic transformation in a thin surface layer [2]. Then, it is interesting to study the damage induced by spherical indentation with a single load cycle, as well as by application of repeated cyclic contact stresses in Y-TZP after a heat treatment at $1650{ }^{\circ} \mathrm{C}$ that gives the 
best combination of mechanical properties. The response of polished and annealed specimens is compared with that of specimens with compressive residual stresses induced by grinding.

\section{EXPERIMENTAL PROCEDURE}

The starting material was Y-TZP with $2.5 \%$ molar of yttria in the shape of rods of $8 \mathrm{~mm}$ diameter and $63 \mathrm{~mm}$ in length. Discs of about $1 \mathrm{~mm}$ thickness were sliced from the rod and heat treated at $1650{ }^{\circ} \mathrm{C}$ during 40 minutes. The resulting heat-treated materials will be referred as $40 \mathrm{M}$. The discs were carefully ground and polished to 1-mm thickness with diamond pastes of different particle size using 30, 6 and $3 \mu \mathrm{m}$ for the last steps.

The microstructure that results from thermal treatment was analysed by means of optical microscopy, scanning electron microscopy and Raman spectroscopy. The strength of the discs was measured by means of biaxial testing in the ball on three ball test [3], by using cemented carbides spheres of $1.98 \mathrm{~mm}$ diameter.

Fracture toughness was measured by introducing a small circular crack by Vickers indentation at the surface of the discs and measuring the strength. The Vickers indent was applied with an inclination of five degrees with respect to the direction perpendicular to the surface in a disc of $2 \mathrm{~mm}$ in thickness. Then the indentation imprint and the plastic ligament located below the indent and the smaller Palmqvist crack were removed by grinding and polishing leaving at the end only a short semi-elliptical crack at the centre of the disc. Finally, the opposite face of the disc was ground and polished in order to reduce the thickness of the disc to 1 $\mathrm{mm}$ followed by a thermal treatment at $1100{ }^{\circ} \mathrm{C}$ in order to remove any residual stress.

The discs were also ground under a pressure of $0.9 \mathrm{MPa}$ with a diamond disc of $68 \mu \mathrm{m}$ particle size and the magnitude and profile of the surface residual stresses induced were measured by X-ray diffraction. No phase transformation was detected on the surface by Raman and $\mathrm{X}$-ray diffraction on specimens heat treated for 40 minutes at $1650{ }^{\circ} \mathrm{C}$. Further analysis of the ground specimens was carried out by indentation techniques (see Fig. 3). The increase in apparent fracture toughness caused by residual stresses was about $30 \%$ of the real fracture toughness and the maximum compressive load in the surface layer was about $1.2 \mathrm{GPa}$. It was also shown that by removing a thin layer of about $10 \mu \mathrm{m}$ in depth in the ground specimens and indenting the length of the cracks were again equal than in polished and annealed specimens [4].

Contact loads were applied at the centre of the discs in annealed and in ground specimens with the same cemented carbide balls in an Instron servohydraulic fatigue testing machine by using load-unload cycles. The strength degradation of the discs was measured by the reduction in the biaxial strength. The minimum number of tests carried out for each condition was 10 , so that each experimental point corresponds to the average of 10 tests. The damage induced by one single cycle was compared to that induced by repeated number of cycles and the damage under the contact surface was analysed by means of SEM.

\section{RESULTS}

The microstructure of $40 \mathrm{M}$ is shown in Fig. 1, where it can be seen that there is a duplex microstructure in which the small grains are tetragonal while the bigger ones correspond to cubic crystallographic structure but they are full of small non-transformable tetragonal precipitates which could form during cooling. The biaxial strength in $40 \mathrm{M}$ (grinding pressure

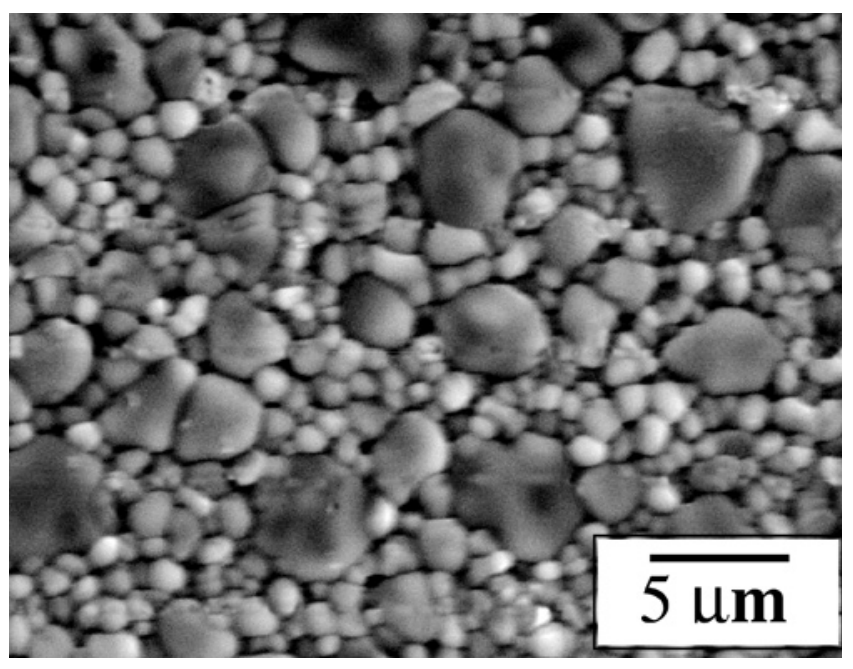

Figure 1: Microstructure of $40 \mathrm{M}$ after exposure at $1650^{\circ} \mathrm{C}$ for $40 \mathrm{~min}$. [Figura 1: Microestrutura da amostra 40M após tratamento térmico a $1650^{\circ} \mathrm{C}$ por $\left.40 \mathrm{~min}.\right]$

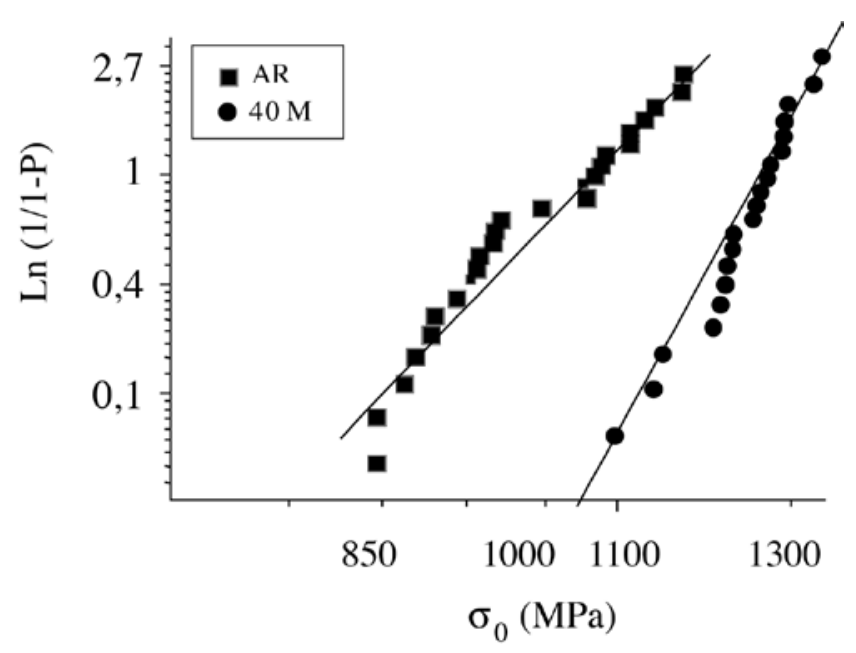

Figure 2: Weibull graphs for AR and 40M.

[Figura 2: Gráficos de Weibull das amostras AR e 40M.] 
$0.9 \mathrm{MPa}$ ) is $1506 \mathrm{MPa}$ in front $1188 \mathrm{MPa}$ in the as received Y-TZP (Fig. 2). The values of the characteristic strength, calculated from a population of 30 specimens, are $1506 \mathrm{MPa}$ and $1188 \mathrm{MPa}$, respectively, and in both cases the modulus of Weibull was around 16.6. The increase in biaxial strength in $40 \mathrm{M}$ is related to an increase in fracture toughness which increases from 4.3 in the starting Y-TZP to $7.1 \mathrm{MPa} \mathrm{m}^{1 / 2}$ for 40M [4].

The biaxial strength has been obtained using the expression proposed by Shetty et al [4]. The biaxial strength does not change after a single load contact cycle if the maximum contact load is smaller than a threshold value, which is $500 \mathrm{~N}$ for $40 \mathrm{M}$ (see Fig. 3). For higher contact loads the drop in strength increases with the maximum cyclic contact load but this dependence is weaker at higher loads.

The influence of the repeated load-unloading during a given number of cycles $\left(10^{3}\right)$ on the strength degradation is shown in Fig. 4 in terms of the maximum load per cycle. It may be noticed the strength degradation under cyclic loading

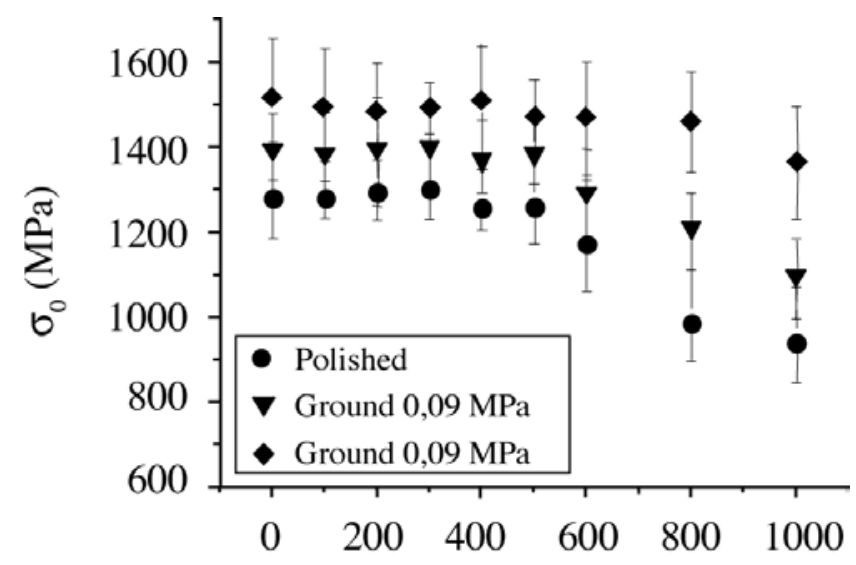

Figure 3: Strength graph of 40M polished and ground 0.9 MPa vs indentation load.

[Figura 3: Gráfico de resistência da amostra 40M polida e seccionada (0,9 MPa) em função da carga de indentação.]

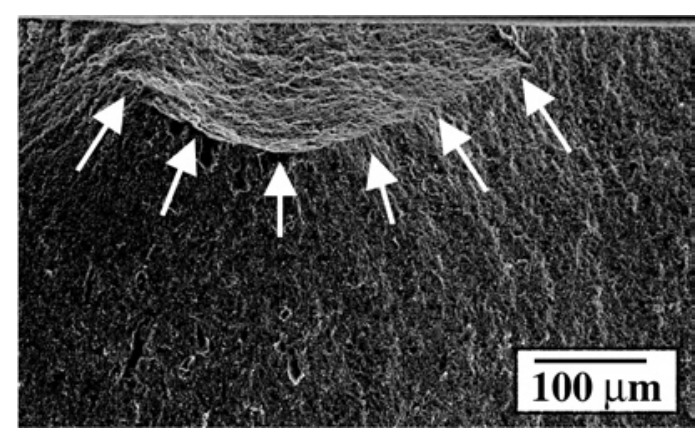

Figure 5: Fracture surface of polished sample (single cycle, $1000 \mathrm{~N}$ ). [Figura 5: Superfície de fratura da amostra polida (um ciclo, $1000 \mathrm{~N})$. is larger than for a single cycle, and that the threshold fatigue load for degradation under cyclic contact loading is only about $200 \mathrm{~N}$.

From the analysis of the fracture surface of the discs it can be seen a semi-elliptical region below the indentation which appearance is clearly different from the rest. This zone has a depth slightly larger than $a / 2$ where $a$ is the radius of the contact zone.

For one single cycle in the annealed and polished specimens it appears that fracture starts from the damage induced under the contact zone. However, after fatigue contact loading for $10^{3}$ cycles, very clear semi-elliptical cracks on the fracture surface which have the same appearance as Palmqvist cracks in Vickers indentation (Fig. 6). However, it is interesting to note that by stopping the fatigue tests, the traces of these cracks could not be detected on the surface of the disc before fracture.

In this sense, it appears that in annealed specimens the mechanism of damage induced under repeated loading

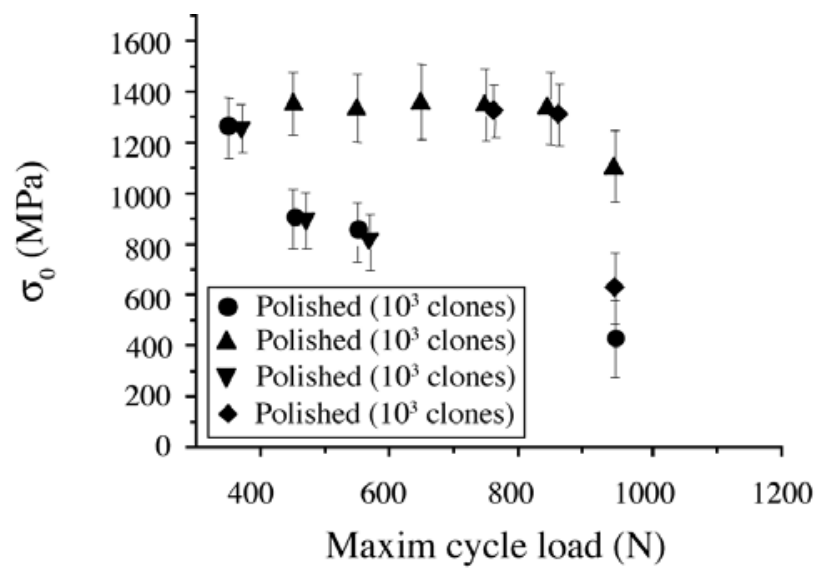

Figure 4: Strength graph of 40M polished and ground 0.9 MPa vs maxim cycle load.

[Figura 4: Gráfico de resistência da amostra 40M polida e seccionada (0,9 MPa) em função da carga de ciclo máximo.]

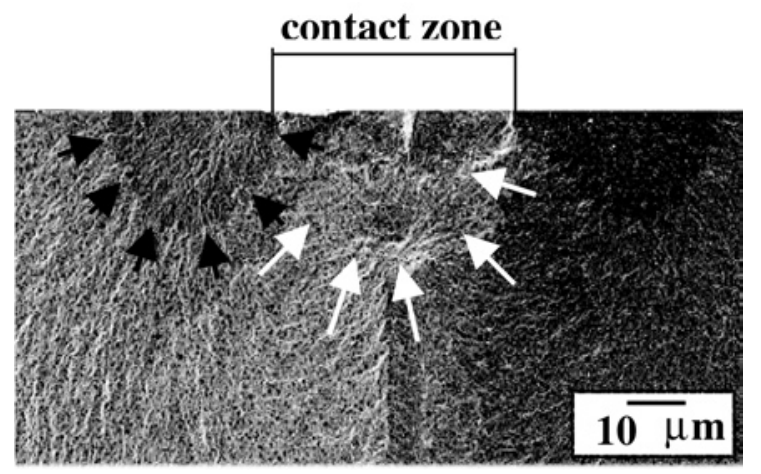

Figure 6: Fracture surface of polished sample (fatigue contact, $1000 \mathrm{~N} 10^{3}$ cycles).

[Figura 6: Superfície de fratura da amostra polida (contato de fadiga, $1000 \mathrm{Ne} 10^{3}$ (iclos).] 


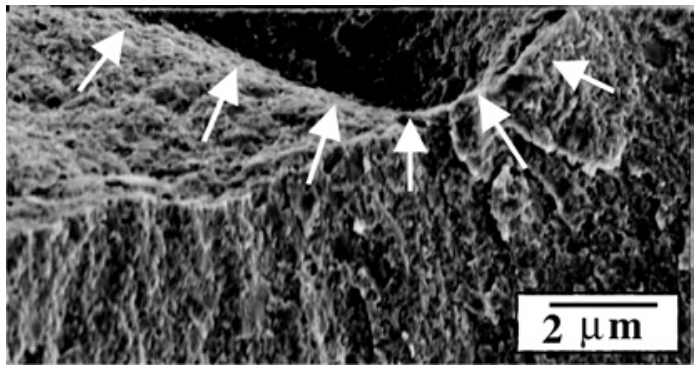

Figure 7: Fracture surface of ground sample 0.9 MPa (single cycle, $1000 \mathrm{~N})$.

[Figura 7: Superficie de fratura da amostra seccionada sob carga de 0,9 MPa (um ciclo, $1000 \mathrm{~N})$.]

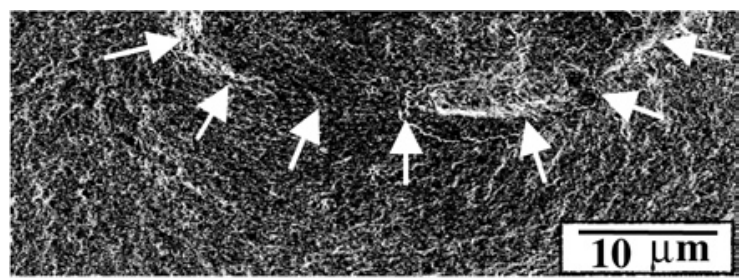

Figure 8: Fracture surface of ground sample $0.9 \mathrm{MPa}$ (fatigue contact, $1000 \mathrm{~N} 10^{3}$ cycles).

[Figura 8: Superficie de fratura da amostra seccionada sob carga de 0,9 MPa (contato de fadiga, $1000 \mathrm{Ne} 10^{3}$ ciclos]

is quite different from that under one single cycle. It is proposed that this radial cracks extent during cycling under residual contact cyclic stresses until the environmental assisted crack propagation threshold is reached. This could also explain the fact that the strength after $10^{5}$ cycles under the same maximum cyclic contact load is the same as after only $10^{3}$ cycles.

The influence of grinding on the response to contact loading is illustrated in Fig. 7. It is quite clear that the damage induced by contact loading is smaller with respect to annealed specimens, and, in addition, damage diminishes with grinding pressure. The effect of grinding residual stresses is still higher in cyclic contact loading where the threshold contact stress for damage increases with grinding.

Main differences on fracture surfaces of ground specimen with respect to annealed specimens is that no damage in the form of radial cracks could be detected and that the semi-elliptical shape below the contact zone is smaller (see Fig. 8).

\section{DISCUSSION}

It is well known [5] that when a stress is applied perpendicularly to a surface by means of a rigid sphere of radius $R$, if there is only elastic deformation, the stresses under the contact zone are well characterized, and very high hydrostatic and shear stress components are reached at a depth below the contact zone equal to about the radius of contact. Tensile stresses are high only in a very small region at the surface just near the circle of contact. When the load is high there in "fragile" materials there is the formation of the system ring-cone crack in those places where the tensile stress is highest, while for tougher material the damage is concentrated only below the surface of contact where the maximum shear stress is reached and it grows to the interior and to the surface when than contact load increases [5]. The high components of the tensile stresses below the contact induce the transformation of the metaestable tetragonal phase to monoclinic symmetry [6], and this is accompanied by micro cracking because of the expansion that accompanies this transformation.

The radial semi-elliptic cracks observed after cyclic contact stresses can not originate from the extension of small defects at the surface near the contact cycle under fluctuations of the elastic tensile stresses since this can produce only ring cracks which propagate towards the interior a few microns. The shape of the observed cracks is similar to that induced by residual tangential tensile stresses with Vickers indenters. The shape of the cracks after cyclic contact stresses is such that $\mathrm{a} / \mathrm{c}>1$, which can be achieved only if the stress at the deepest point of the crack is high enough and this is not the case for elastic tensile stresses, that is, the small cracks generated at the surface by the high elastic stresses can be extended by the residual inelastic component during fatigue until the residual driving stress is lower than the threshold stress intensity factor for fatigue crack growth. This could also explain the fact that the strength after $10^{5}$ cycles under the same maximum cyclic contact load is the same as after only $10^{3}$ cycles.

The application of a load $\mathrm{P}$ by hertzian contact induces high stress levels below the contact zone where the tetragonalmonoclinic of zirconia may occur, which also nucleates microcracks because of the dilation that accompanies this transformation. This inelastic deformation induces residual stresses in the unloading part of the cycle. This is well known during Vickers indentation [8]. If the indenter is spherical with a very small radius, and the fracture toughness is high enough, so that cone cracks are prevented, it is also possible that radial cracks are formed in zirconia. According to Marshall [9] and with some recent work by Suganuma [10] the radial cracks around spherical indentations are controlled by the residual stress field that depends on the volume of the indentation. Thus, Suganuma [10] found radial cracks in Y-TZP by using a conical indenter with a tip radius of $0.2 \mathrm{~mm}$ and an angle of $120^{\circ}$ and whose lengths were only about 20 and $25 \%$ shorter that those produced by Vickers indentation.

In Fig. 6 one can see that the crack geometry is only slightly semi-elliptical with $\mathrm{c}=120 \mu \mathrm{m}, \mathrm{a}=150 \mu \mathrm{m}$, for the crack at the left, and $\mathrm{c}=160 \mu \mathrm{m}$ and $\mathrm{a}=140 \mu \mathrm{m}$ for the crack at the right. Since the toughness of $40 \mathrm{M}$ is $7,1 \mathrm{MPam}^{1 / 2}$, it is possible to estimate the strength by assuming that this is the critical defect 
and that the indentation residual stresses have been relaxed by crack growth. It is then surprising to find a too good correlation between the calculated strength $(464 \mathrm{~N})$ and the experimental strength $(450 \mathrm{~N})$ in view of the neglected residual stresses. Since the crack has propagated during contact loading, the final residual SFI should be small and this probably will not strongly affect the above estimation.

\section{CONCLUSIONS}

It is concluded that residual surface stresses produced by grinding in Y-TZP 40M increase drastically the strength as well as the resistance to damage by contact loading. The effect is larger for cyclic contact loading. The damage induced by cyclic contact loading is larger than that produced by one cycle either in polished or ground specimens. Under all material and testing conditions a damage zone is produce below the contact zone, but after contact loading for many cycles some radial cracks whose propagation during contact loading may be related to the damage under these testing conditions. This mechanism is expected to be more relevant when the amount of irreversible deformation is higher; the higher is the contact pressure, and when the materials have a higher toughness.

\section{ACKNOWLEDGEMENTS}

The authors acknowledge the Ministerio de Ciencia y Tecnología for financial support through the project MAT2002-00368 and the Generalitat de Catalunya for grant No.2001SGR00229. A. J. acknowledges the financial support provided through the Agencia Española de Cooperación Internacional and E. J. P. acknowledges the Generalitat de Catalunya for financial support through grant 2003RED00042

\section{REFERENCES}

[1] D. J. Green, R. H. J. Hannink, M. V. Swain, Transformation Toughening of Ceramics, CRC Press Inc., Florida, USA (1989).

[2] W. Pfeiffer, M. Rombach, E. Sommer, "Assessment of strength-dominating near-surface-characteristics of machined ceramics", Fracture Mechanics of Ceramics 11 (1996) 401.

[3] B. Eigenmann, E. Macherauch, "Determination of inhomogeneous stress in layers of machined ceramics by synchrotron X-rays", Nuclear Inst. Meth. Phys. Res. 97 (1995) 92.

[4] D. K. Shetty, A. R. Rosenfield, P. McGuire, G. K. Bansal, W. H. Duckworth, "Biaxial Fracture Test for Ceramics”, J. Am. Ceram. Soc. 64 (1981) 1.

[5] A. Juy, "Influencia de las tensiones residuales de mecanizado en las propiedades mecánicas de Y-TZP", Ph.D Thesis, Universitat Politècnica de Catalunya (2004).

[6] B. R. Lawn, "Indentation of Ceramics with Spheres: A Century after Hertz,” J. Am. Ceram. Soc. 81 (1998) 1977.

[7] A. Pajares, L. Wei, B. R. Lawn, D. B. Marshall, "Damage Accumulation and Cyclic Fatigue in Y-PSZ at Hertzian Contacts", J. Mater. Res. 10 (1995) 2613.

[8] B. R. Lawn, "Fracture of Brittle Solids", Cambridge University Press, Cambridge, Chapt. 8 (1993).

[9] D. B. Marshall, "Geometrical Effects in ElasticPlastic Indentation", J. Am. Ceram. Soc. 67 (1983) 57.

[10] M. Suganuma, "Spherical and Vickers Indentation Damage in Yttria-Stabilized Tetragonal Zirconia Polycrystals", J. Am. Ceram. Soc. 82 (1999) 3113.

(Rec. 16/02/2005, Ac. 30/05/2005) 